\title{
Pengaruh model pembelajaran inkuiri terbimbing terhadap hasil belajar ipa siswa kelas VIII SMP/MTs
}

\author{
Firda Awalia Putri, Susriyati Mahanal*, Vita Ria Mustikasari \\ Universitas Negeri Malang, Jl. Semarang No. 5 Malang, Jawa Timur, Indonesia \\ *Penulis korespondensi, Surel: susriyati.mahanal.fmipa@um.ac.id
}

Paper received: 01-02-2021; revised: 15-02-2021; accepted: 28-02-2021

\begin{abstract}
The aim of this study is to analyze the difference of students learning result on Natural Science subject who study using guided inquiry and conventional learning. The subjects of this study involve the students VIII grade of MTs Negeri Malang III that selected by cluster random sampling. The measurement of students learning result through posttest of multiple choice item which is analyzed is using precondition test and t-test. The result of study showed that there was a difference on students learning result who learnt using guided inquiry learning and those who used conventional learning
\end{abstract}

Keywords: guided inquiry; learning result

\begin{abstract}
Abstrak
Penelitian ini bertujuan untuk menganalisis perbedaan hasil belajar IPA peserta didik yang belajar dengan pembelajaran inkuiri terbimbing dan pembelajaran konvensional. Subjek penelitian ini adalah peserta didik kelas VIII MTs Negeri Malang III yang dipilih secara cluster random sampling. Pengukuran hasil belajar peserta didik melalui posttest soal pilihan ganda yang dianalisis menggunakan uji prasyarat dan uji-t. Hasil penelitian ini menunjukkan bahwa terdapat perbedaan hasil belajar peserta didik yang belajar dengan pembelajaran inkuiri terbimbing dan peserta didik yang belajar dengan pembelajaran konvensional.
\end{abstract}

Kata kunci: inkuiri terbimbing; hasil belajar

\section{Pendahuluan}

Ilmu Pengetahuan Alam (IPA) merupakan cabang pengetahuan yang berawal dari fenomena alam dan kehidupan sehari-hari. IPA meliputi dua cakupan yaitu IPA sebagai produk dan IPA sebagai proses. IPA sebagai produk meliputi kumpulan pengetahuan yang terdiri dari fakta, konsep, dan prinsip. IPA sebagai proses meliputi keterampilan ilmiah (Yuliati, 2008). Kegiatan belajar IPA tidak hanya mengutamakan hasil namun juga proses pembelajarannya.

Proses pembelajaran IPA pada kurikulum 2013 berorientasi pada pendekatan ilmiah yang mengarahkan peserta didik aktif dalam pembelajaran. (Kemendikbud, 2013). Pembelajaran IPA SMP menurut permendikbud no 64 tahun 2013 tentang Standar Isi bertujuan untuk membentuk peserta didik yang memiliki sifat ilmiah, mengajukan pertanyaan tentang fenomena IPA, melaksanakan percobaan, mencatat dan menghasilkan penyelidikan, menyimpulkan dan melaporkan, memahami konsep dan prinsip IPA beserta kaitannya dan diterapkan dalam menyelesaikan masalah. Pencapaian tujuan pembelajaran tersebut dapat dilaksanakan dengan menekankan pembelajaran IPA pada keaktifan dan keterlibatan peserta didik dalam memproses untuk mengolah informasi agar peserta didik lebih mudah memahami, mengerti, dan meresapi konsep IPA. Guru dalam proses pembelajaran tidak hanya menstransfer ilmu saja tetapi juga membantu proses pemahaman 
materi pelajaran melalui pemilihan model pembelajaran yang sesuai dengan perkembangan ilmu pengetahuan (Dewi, 2013).

Kenyataan yang ada di lapangan menunjukkan bahwa proses pembelajaran cenderung bersifat teoritis dan berpusat pada guru. Pada pembelajarannya guru menjadi sumber pengetahuan, sehingga peserta didik bersifat pasif dalam proses pembelajaran (Wulanningsih, 2012). Penelitian Dewi (2013) menyatakan bahwa 60\% peserta didik mendapatkan nilai di bawah Kriteria Ketuntasan Minimal (KKM) pada mata pelajaran IPA, hal ini disebabkan pada pembelajaran IPA yang ada di sekolah cenderung menggunakan pendekatan ekspositori dan guru jarang memberikan kesempatan kepada peserta didik untuk melakukan pengamatan atau eksperimen. Berdasarkan penjelasan diatas dapat disimpulkan bahwa pembelajaran yang berpusat pada guru dan tidak melibatkan peran aktif peserta didik menyebabkan rendahnya hasil belajar peserta didik.

Pembelajaran yang berpusat pada guru terlihat bertentangan dengan pembelajaran pada kurikulum 2013. Kemendikbud (2013) menyatakan bahwa pembelajaran menuntut ilmu untuk mencari tahu bukan diberi tahu. Pembelajaran akan lebih bermakna apabila siswa menemukan sendiri konsep yang dipelajari melalui proses ilmiah. Kegiatan pengamatan atau eksperimen dapat menimbulkan dan mengembangkan sikap ilmiah pada peserta didik (Dewi, 2013). Ozlidek (2009) mengungkapkan bahwa pembelajaran inkuiri atau penemuan mampu membuat pembelajaran lebih bermakna dalam mempelajari konsep yang abstrak.

Pembelajaran inkuiri menurut National Research Council (2000) dimaknai sebagai pembelajaran yang memiliki multitahapan kegiatan, yaitu melibatkan observasi, mengajukan pertanyaan, mengkaji buku atau sumber informasi lainnya, merancang penyelidikan, mengkaji ulang pengetahuan yang dimiliki untuk memecahkan fakta eksperimen, mengumpulkan data, menganalisis, menginterpretasikan data, mengajukan jawaban, menjelaskan dan memprediksi serta mengkomunikasikan hasil yang diperoleh. Berdasarkan karakteristiknya, terdapat keselarasan antara pembelajaran IPA dengan pembelajaran inkuiri. Model pembelajaran inkuiri dapat membantu peserta didik membangun konsep dengan memperoleh pengalaman melalui kegiatan ilmiah.

Beberapa penelitian telah banyak dilakukan untuk mengetahui keefektifan dari pembelajaran inkuiri terbimbing, di antaranya penelitian yang dilakukan oleh Ifeoma \& Oge (2013) yang menunjukkan bahwa pembelajaran inkuiri terbimbing dapat meningkatkan prestasi belajar dan partisipasi peserta didik dibanding pembelajaran konvensional. Penelitian Dewi (2013) menunjukkan bahwa hasil belajar peserta didik yang belajar dengan model pembelajaran inkuiri terbimbing lebih baik dari pada kelompok peserta didik yang belajar dengan model pembelajaran konvesional. Penelitian lain yang mendukung hal ini adalah penelitian Putri (2015) yang menyatakan bahwa penerapan strategi pembelajaran inkuiri terbimbing dapat meningkatkan hasil belajar peserta didik kelas VIII SMP 2 Maesan secara signifikan.

Berdasarkan uraian diatas, maka penting dilakukan penelitian lebih lanjut terkait hasil belajar peserta didik dengan model pembelajaran inkuiri terbimbing. Model pembelajaran inkuiri terbimbing diharapkan dapat memberikan pengalaman belajar bagi peserta didik terutama pada hasil belajar. 


\section{Metode}

Penelitian kuantitatif jenis eksperimen semu (Quasi-Experimental) ini menggunakan desain posttest-only control group design. Populasi dalam penelitian ini adalah siswa kelas VIII MTs Negeri Malang III tahun pelajaran 2015/2016. Penelitian ini menggunakan dua kelas penelitian yaitu kelas eksperimen dan kelas kontrol yang dipilih secara Cluster Random Sampling. Kelas eksperimen adalah kelas VIII F yang belajar dengan menggunakan pembelajaran inkuiri terbimbing dan kelas kontrol adalah kelas VIII G yang belajar dengan menggunakan pembelajaran konvensional. Instrumen dalam penelitian ini meliputi: 1) instrumen perlakuan yaitu: Silabus, Rencana Pelaksanaan Pembelajaran (RPP), dan Lembar Kerja Peserta didik, dan 2) instrumen pengukuran yaitu: butir soal pilihan ganda yang digunakan untuk mengukur kemampuan kognitif peserta didik. Pengumpulan data dilakukan dengan cara posttest.

\section{Hasil dan Pembahasan}

\section{Deskripsi Data Keterlaksanaan Pembelajaran}

Hasil rata-rata observasi keterlaksanaan proses pembelajaran terhadap aktivitas guru pada kelas ekperimen dan kelas kontrol disajikan pada Tabel 1.

Tabel 1. Persentase Keterlaksanaan Pembelajaran

\begin{tabular}{lll}
\hline \multirow{2}{*}{ Pertemuan Ke- } & Persentase Keterlaksanaan & \\
\cline { 2 - 3 } & Kelas Eksperimen & Kelas Kontrol \\
\hline 1 & $93,33 \%$ & $91,67 \%$ \\
2 & $86,67 \%$ & $100 \%$ \\
3 & $86,67 \%$ & $83,33 \%$ \\
4 & $86,67 \%$ & $91,67 \%$ \\
\hline Rata-rata & $93,33 \%$ & $83,33 \%$ \\
\hline
\end{tabular}

Data pada Tabel 1 menunjukkan bahwa rata-rata presentase keterlaksanaan pembelajaran pada kelas eksperimen mencapau $89,34 \%$ dan pada kelas kontrol mencapai rata-rata $90 \%$. Hasil ini termasuk dalam kategori sangat efektif.

\section{Analisis Kemampuan Awal Peserta Didik}

Data kemampuan awal peserta didik dianalisis dengan menggunakan uji-t untuk mengetahui ada atau tidaknya perbedaan kemampuan awal peserta didik sebelum diberi perlakuan berupa model pembelajaran yang berbeda. Uji tersebut bertujuan untuk membuktikan bahwa hasil posttest peserta didik yang berbeda pada akhir pembelajaran benar-benar disebabkan oleh perbedaan perlakuan yang diberikan pada kedua kelas.Sebelum melakukan uji-t, data kemampuan awal peserta didik telah dilakukan uji prasyarat analisis yang meliputi uji normalitas dan uji homogenitas. Hasil uji prasyarat analisis diperoleh bahwa data berdistribusi normal dan memiliki varian homogen. Hasil uji-t data kemampuan awal peserta didik disajikan pada Tabel 2. 
Tabel Hasil Uji-t Kemampuan Awal Peserta Didik

\begin{tabular}{llll}
\hline Kelas & Nilai signifikansi & $\alpha$ & Kesimpulan \\
\hline $\begin{array}{l}\text { Eksperimen } \\
\text { Kontrol }\end{array}$ & 0,053 & 0,05 & $\begin{array}{l}\text { Tidak terdapat perbedaan } \\
\text { kemampuan awal }\end{array}$ \\
\hline
\end{tabular}

Tabel 2 menunjukkan bahwa kemampuan awal peserta didik kelas ekperimen dan kelas kontrol memiliki nilai signifikansi lebih besar dari 0,05 yaitu sebesar 0,053. Berdasarkan hal ini dapat disimpulkan bahwa tidak ada perbedaan kemampuan awal antara peserta didik kelas eksperimen dan kelas kontrol.

\section{Analisis Hasil Belajar Peserta Didik}

Data hasil belajar peserta didik diperoleh dari posttest berupa soal pilihan ganda. Data hasil belajar dianalisis secara statistik menggunakan uji-t. sebelum menggunakan uji-t maka harus dilakukan uji prasyarat yaitu uji normalitas dan uji homogenitas. Hasil uji prasyarat analisis diperoleh bahwa data terdistribusi normal dan memiliki varian homogeny. Hasil uji data posttest hasil belajar peserta didik disajikan pada Tabel 3.

Tabel Hasil Uji-t Data Posttest Hasil Belajar Peserta Didik

\begin{tabular}{llll}
\hline Kelas & Nilai signifikansi & $\alpha$ & Kesimpulan \\
\hline $\begin{array}{l}\text { Eksperimen } \\
\text { Kontrol }\end{array}$ & 0,001 & 0,05 & $\begin{array}{l}\text { Terdapat perbedaan hasil } \\
\text { belajar }\end{array}$ \\
\hline
\end{tabular}

Tabel 3 menunjukkan bahwa hasil uji-t data posttest hasil belajar peserta didik yaitu kurang dari 0,05 yaitu 0,001. Berdasarkan hasil tersebut dapat disimpulkan bahwa terdapat perbedaan antara hasil belajar peserta didik yang belajar dengan pembelajaran inkuiri terbimbing dengan pembelajaran konvensional.

\section{PEMBAHASAN}

Pengujian hipotesis yang telah dilakukan menunjukkan bahwa terdapat perbedaan hasil belajar peserta didik yang belajar dengan model pembelajaran inkuiri terbimbing dan peserta didik yang belajar dengan pembelajaran konvensional. Hasil tersebut dibuktikan berdasarkan analisis menggunakan uji-t pada Tabel 4.5 dengan nilai signifikansi sebesar 0,001 lebih kecil dari 0,05. Hasil belajar peserta didik yang belajar dengan inkuiri terbimbing lebih tinggi daripada peserta didik yang belajar dengan pembelajaran konvensional. Nilai rata-rata pada kelas inkuiri terbimbing sebesar 82,40 dan nilai rata-rata kelas pembelajaran konvensional sebesar 76,47.

Pembelajaran inkuiri terbimbing dilakukan sebanyak 5 kali tatap muka. Hasil penelitian menunjukkan bahwa pembelajaran inkuiri terbimbing ini terbukti mendorong peserta didik untuk mengajukan pertanyaan tentang topik yang dipelajari dan mengekplorasi jawaban atas pertanyaan yang diajukan. Penerapan pembelajaran inkuiri terbimbing guru sedikit berbicara, tetapi sering mengajukan pertanyaan atau masalah. Pengajuan pertanyaan dari guru dapat membantu peserta didik menggunakan pemikirannya. Menurut Redhana (2007) pertanyaan yang sesuai akan dapat membimbing dan memberi isyarat agar mereka dapat menemukan jawaban sendiri. 
Pembelajaran inkuiri terbimbing dalam proses pembelajaran IPA menjadikan peserta didik untuk lebih aktif dalam memperoleh dan menemukan konsep dari fenomena lingkungan sekitar. Dewi (2013) menyatakan bahwa pembelajaran inkuiri terbimbing memberikan peluang kepada peserta didik untuk aktif sehingga dapat memperoleh informasi dan melekat pada memori peserta didik. Dengan kuatnya informasi yang didapat peserta didik, dapat berdampak pula pada perolehan hasil belajar peserta didik. Indikator hasil belajar yang dapat diukur dalam penelitian ini adalah mengingat, memahami, mengaplikasi, menganalisis dan mengevaluasi.

Sintaks pembelajaran inkuiri terbimbing menjadikan peserta didik lebih mandiri dalam melakukan menyelesaikan masalah dengan bimbingan guru. Sintaks pembelajaran inkuiri terbimbing yaitu mengajukan pertanyaan, merumuskan masalah dan hipotesis, merancang dan melakukan percobaan, menganalisis hasil dan menyimpulkan dapat meningkatkan hasil belajar peserta didik. Pada pembelajaran inkuiri terbimbing peserta didik diberi kesempatan untuk berpartisipasi dalam pembelajaran dimana guru bertugas membimbing peserta didik dalam menemukan pola dan menyampaikan kesimpulan (Jacobsen, dkk., 2009).

Hasil penelitian ini juga didukung oleh penelitian sebelumnya yang menunjukkan hasil yang sama. Penelitian Ifeoma dan Oge (2013) yang menunjukkan bahwa pembelajaran inkuiri dapat meningkatkan prestasi belajar dan partisipasi siswa dibanding pembelajaran konvensional, kemudian penelitian yang dilakukan oleh Matthew dan Igharo (2013) yang menunjukkan hasil belajar siswa yang dibelajarkan dengan pembelajran inkuiri terbimbing lebih baik daripada siswa yang dibelajarkan dengan pembelajaran konvensional. Penelitian Dewi (2013) menunjukkan bahwa hasil belajar siswa yang belajar dengan model pembelajaran inkuiri terbimbing lebih baik dari pada kelompok siswa yang belajar dengan model pembelajaran konvesional. Penelitian lain yang mendukung hal ini adalah penelitian Putri (2015) yang menyatakan bahwa penerapan strategi pembelajaran inkuiri terbimbing dapat meningkatkan hasil belajar siswa kelas VIII SMP 2 Maesan secara signifikan.

\section{Simpulan}

\section{Kesimpulan}

Berdasarkan analisis data dan pembahasan yang berkaitan dengan rumusan masalah, maka dapat disimpulkan bahwa terdapat perbedaan hasil belajar siswa yang dibelajarkan dengan pembelajaran inkuiri terbimbing dengan siswa yang dibelajarkan dengan pembelajaran konvensional. Hasil belajar siswa dengan pembelajran inkuiri terbimbing lebih tinggi dibanding hasil belajar siswa dengan pembelajaran konvensional.

\section{Saran}

Bagi guru, hasil penelitian ini diharapkan dapat menjadi referensi dalam mengimplementasikan pembelajaran inkuiri terbimbing di sekolah untuk meningkatkan hasil belajar.

Bagi guru dan bagi peneliti lain, diharapkan memperhatikan alokasi waktu, karena dalam pembelajaran IPA khususnya dengan topik cahaya dan alat optik diperlukan waktu yang relatif lama. 


\section{Daftar Rujukan}

Council, N. (2000). Inquiry and the national science education standards: A guide for teaching and learning. Science Education.

David A., Jacobsen, at. All. (2009). Methods for teaching. Yogyakarta: Pustaka Pelajar.

Dewi, N. L., Dantes, N., \& Sadia, I. W. (2013). Pengaruh model pembelajaran inkuiri terbimbing terhadap sikap ilmiah dan hasil belajar IPA (Doctoral dissertation, Ganesha University of Education).

Ifeoma, O. E., \& Oge, E. K. (2013). Effects of Guided Inquiry Method on Secondary School Students' Performance in Social Studies Curriculum in Anambra State, Nigeria. Journal of Education, Society and Behavioural Science, 206-222.

Kemendikbud. (2013). Materi Pelatihan Guru: Implementasi Kurikulum 2013 SMP/MTs Ilmu Pengetahuan Alam. Jakarta: Badan Pengembangan Sumber Daya Manusia Pendidikan dan Kebudayaan dan Penjaminan Mutu Pendidikan.

Matthew, B. M., \& Kenneth, I. O. (2013). A study on the effects of guided inquiry teaching method on students achievement in logic. International Researcher, 2(1), 135-140.

Özdilek, Z., \& Bulunuz, N. (2009). The effect of a guided inquiry method on pre-service teachers' science teaching self-efficacy beliefs. Journal of Turkish Science Education, 6(2), 24-42.

Permendikbud, R. I. No. 64 Tahun 2013 Tentang Standar Isi Pendidikan Dasar dan Menengah. Jakarta: Kemendikbud.

Putri, Yulian., Suratno, dan Aisyiah, Iis Nur. (2015). Pengaruh Model Pembelajaran Inkuiri Terbimbing (Guided Inquiry) dengan Menggunakan Metode Eksperimen Terhadap Aktivitas dan Hasil Belajar IPA Biologi Siswa Kelas VIII SMP Negeri Maesan Bondowoso. Pancaran. (Online), (4)2:163-172), (jurnal.unej.ac.id)

Redhana, N. (2007). Meningkatkan Profesionalisme Guru Melalui Pembelajaran Inovatif.

Wulanningsih, S. (2012). Pengaruh model pembelajaran inkuiri terbimbing terhadap keterampilan proses sains ditinjau dari kemampuan akademik siswa SMA Negeri 5 Surakarta.

Yuliati, Lia. (2008). Model-Model Pembelajaran Fisika. Malang: Lembaga Pengembangan Pendidikan dan Pembelajaran Universitas Negeri Malang. 